\title{
RECONSTRUCTION OF LEGAL LIABILITY OF REGISTRATION BY NOTARY FIDUCIARY BASED ON PP No. 21 of 2015
}

\author{
Wieke Dewi Suryandari \\ Semarang notary \\ wiekedewi66@yahoo.com
}

\begin{abstract}
Fiduciary term that has long been known in the Indonesian language. Similarly, the term is used in Act No. 42 of 1999 regarding Fiduciary. In the terminology of the Dutch term is often referred to in full, namely Fiduciare Eigendom Overdracht (FEO), namely the delivery of property rights in the trust. The methods used in this study, using juridical-empirics. Judicial approach used to analyze the various rules and regulations governing the fiduciary agreement and fiduciary While the English term is called Fiduciary Transfer of Ownership.Background onset of fiduciary institutions, as set out by the experts is because the statutory provisions governing the institution pand (pawn) contains many flaws, does not meet based on developments in its history, Fiduciary originated from an agreement that only is basedon trust. But over time in practice the necessary legal certainty to protect the interests of the parties and the needs of society.
\end{abstract}

Keywords: Fiduciary; Public Notary; Reconstruction of Law.

\section{A. INTRODUCTION}

The dynamics of economic globalization which increasingly advanced today, pushing all countries in all over the world continue to run fast in reforming all of its economic policies. However, in the field of economic implementation, the law policy sometimes cannot escape from controversy in society. ${ }^{1}$ Fiduciary is security interests in the moving objects both tangible and non bewujud ${ }^{2}$ and immovable in particular building can not be encumbered encumbrance as to which referred to in Act No. 4 of 1996 on Mortgage which remain in control of the Giver Fiduciary (debtors), as collateral for the repayment of certain

${ }^{1}$ I. Gusti Ayu Ketut Rachmi Handayani, Edi As'Adi, Guntur Hamzah, Tommy Leonard, Gunarto, Relationship between Energy Consumption in International Market and Indonesia Prices Regulation, International Journal of Energy Economics and Policy, 2017, 7(5), 9-15

2 Sri Soedewi Masjhoen Sofwan, 1977: 15-116 amount of money, which gives the position preferred to fiduciary recipient (creditor) against creditors is lainnya.fiduciary accounts payable treaty creditor to the debtor that involves underwriting. The collateral position still in control of the owner of the guarantee. But in order to ensure legal certainty for creditors then made a agreement made by the notary and registered with the Registry Office fiduciary. Later creditor will obtain a certificate of fiduciary berirah-irah "By Justice Based on God".

Before exiting the Act 42 of 1999 which became the object of fiduciary assurance is moving objects comprising objects in the inventory, merchandise items, accounts receivable, machinery equipment and vehicles with the issuance of Act No. 42 of 1999 objects fiduciary mak given broader sense. Definition of Fiduciary accordance with Act No. 42 of 1999 on Fiduciary is: 
1. The transfer of ownership of an object on the basis of trust with the provision that the object of the transferred ownership rights remain in the control of the owner of the object.

2. Fiduciary is the right collateral to the moving objects both tangible and intangible and immovable in particular building can not be burdened with security rights as stipulated in Act No. 4 of 1996 on Mortgage which remain in control of the Giver Fiduciary, as collateral for the repayment of certain debt, which gives precedence to the Receiver position Fiduciary against other creditors.

According to DR A Hamsah and Senjun Manulang, Fiduciary is: A way of transfer of property rights of the owner (the Borrower) based on their agreement in principal (loan agreement receivables) to creditors, but submitted only right course in Juridical Levering and solely owned by the creditor trust only (as collateral for the debtor) is right goods are still controlled by the debtor but not anymore as eigenaar (owner) and beziter (master) but only as Detentor or Holder and on behalf of the creditor eigenaar. In summary is a way of transfer of property rights of the Borrower to creditors based on their agreement accounts payable,

Fiduciary guarantee is a guarantee of an individual, where the Giver Fiduciary and Receiver Fiduciary provide mutual trust, Giver Fiduciary hand over ownership rights to the Beneficiary Fiduciary, but Recipient Fiduciary indirectly have an object that is a guarantee of fiduciary submitted by Giver Fiduciary, so that fiduciary is a theory guarantee.

In a fiduciary guarantee registration there is a necessity to include objects that become the object of fiduciary. This is very important because it is exactly what objects can be sold for debt payments fiduciary. Object collateral should be understood as the right fiduciary is the right material attached to the object of fiduciary and will keep abreast of any object in the hands of the object is (droit de suite) for the fiduciary has not waived / strikethrough.

Interpret, that should be listed is the bail bond objects and gentlemen, would be very beneficial. Thus, bond guarantees and promises of fiduciary be registered and could therefore be the recipient of fiduciary, while legal protection against fiduciary recipient is given through a fiduciary perjanjianjaminan according bind third parties. $^{3}$ In an underwriting agreement, usually is between creditors and debtors agreed certain promises, which are generally intended to give a strong position for the creditors and will be registered after intended to also bind third parties. Therefore it can be interpreted herein that includes registration, both registration and bond collateral objects, then all the promises contained in the agreement of fiduciary (which in Article 13 paragraph (2) $b$ is recorded in the book list Fiduciary Registration Office) and bind third parties.

Description above shows that the parties to the agreement fiduciary, both recipients of fiduciary and giver of fiduciary statutory fiduciary equally be given legal protection, for giving protection in the form of their right to use the object collateral and defaulting insurer fidak will cause objects guarantee the rights preferent UUJF is given on loans, and the enactment of the principle of droit de suite on collateral objects, for the third party principle of publicity in the

3 Satrio J., 2002, Legal Rights Guarantee Fiduciary material Assurance, PT. Citra Aditya Bakti, Bandung, p. 247 
fiduciary agreement will provide information about fiduciary objects.

However, according to Article 11 UUJF explained that the fiduciary agreement in agreement of notary not enough, but must be registered, agreement of notary an authentic act and can merupakanutorial agreement, the fiduciary agreement notary agreement without registration does not entitle preferent for the recipient fiduciary, so there is no arrangement firm in UUJF about who should execute fiduciary objects, whereas objects fiduciary is a very risky move objects displacement, resulting in a fiduciary recipient field application be difficult to implement the principle of droit de suite.

The inadequacies of protection mentioned above are exacerbated by the actions practical application of the fiduciary agreement in the field, including but not registration, with the object of fiduciary (only stop the manufacture of authentic agreements), for negotiations that provide additional costs for the recipient of fiduciary at the time of executing the object jamainan fiduciary, so the certificate of fiduciary does not provide legal education in society.

Not surprisingly, due to such a peaceful practice, cases of slow and difficult execution of fiduciary become a problem, in prasurvey writers do, eg in some Rural Bank fiduciary agreement is not effective because of difficult implementation of a paradigm eksekusi. according to Aristotle's theory, justice will be felt when the relevant system in the basic structures of a well-ordered society, political, economic and social institutions are satisfactory in relation with the concept of stability and balance ${ }^{4}$ above

4 Anis Mashdurohatun, Redyanto Sidji, Gunarto and Mahmutarom, Factors Causing Banking Cyber Crime authors want to write a dissertation with the title Reconstruction Law Fiduciary Liability on registration conducted by the Notary By PP 21 of 2015

\section{B. Research Methods}

The methods used in this study, using juridical-empirics. Judicial approach used to analyze the various rules and regulations governing the fiduciary agreement and fiduciary. While the empirical approach used to analyze the law not merely as a set of rules of law that are normative, but the law is seen as society implicated the action and patterned in public life. The approach used in the writing problems of this dissertation is socio- legal approach research, it is the study of law to use social science methodology approach in the broadest sense. The paradigm of this research is the Positivism Paradigm, with the type of doctrinal research. Law is defined as the norm or rule that applies in society and becomes the reference of everyone's behavior, and the rules or norms in positive law 5

\section{RESULTAND DISCUSSION}

\section{Fiduciary}

Fiduciary according to his origin comes from the word "Fides", which means trust, In accordance with the meaning of the word is the relationship (legal) between debtors (authorizer) and creditor (endorsee) is a legal relationship

in Indonesian, International Journal of Economic Research, Volume 14 Number 15 2017. P.295

5 Anis Mashdurohatun, Zaenal Arifin and Gunarto, The Inconsistency of Parate Execution Object Warranty of Rights in, International Journal of Applied Business and Economic Research, Volume 15 Number 20 year 2017, p.268

Banking Credit Agreement in Indonesia 
based on trust. ${ }^{6}$ Fiduciary institution already known and ruled in Roman law society. There are two forms namely fiduciary fiduciary and fiduciary creditore cum cum amico. Both arise from the agreement called pactum fiduciae followed by the transfer of rights or in iure cessio. In the first form or full fiduciary creditare cum contractâ which means the promise of trust made by creditors, debtors dikatakan.bahwa transfer the ownership of an object to a creditor as security for his debt with the agreement that the creditor will transfer the ownership back to the debtor if the debt has been paid keel.

Fiduciary is a term that has long been known in the Indonesian language. Legislation that specifically regulates this matter, that UUJF also use the term "fiduciary". Thus, the term "fiduciary" is already an official term in the world of our law. However, sometimes in Indonesian to this fiduciary is also called "Delivery Properties In Trust".

In the Dutch literature fiduciary is known also in terms of the following ${ }^{7}$ :

(1) Zekerheids-eigendom (Hak as Collateral).

(2) Bezitloos Zekerheidsrecht (collateral without Mastering).

(3) Verruimd Pand begrip (Pawn Expanded).

(4) Eigendom Overdracht tot Zekerheid (Delivery Properties - is a guarantee).

(5) Bezitloos Pand (Pledge without Mastery).

6 Gunawan Widjaja and Ahmad Yani, Fiduciary, King Grafindo Persada, Jakarta

7 Sofwan, Sri Soedewi Masjchoen, 1977, Legal guarantees in Indonesia. Principles of the Law of Guarantees and Warranties Individual, National Law Development Agency, Jakarta, p. 27
(6) Een Pand Verkapt Recht (Pawn sheathed).

(7) Uitbaouw Pand (Pawn Expanded).

Some of the main principles and the fiduciary is as follows 8 :

(1) Whereas in real terms, the fiduciary holder works only guarantee holder only, not as the owner of the truth.

(2) Fiduciary rights holders to execute a new guarantee product exists if there is a default of the debtor

(3) If the debt is paid, then the object fiduciary must be returned to the giver fiduciary.

(4) If the proceeds of sale (execution) fiduciary goods exceeds the amount of the debt, the remainder of the proceeds shall be returned to the giver fiduciary.

In addition, for the validity of transfer of rights in the construction of this law, must meet the following requirements:

(1) There is an agreement that is zakelijk.

(2) The Fitel to a transfer of rights.

(3) The authority to mengiiasai bodies of people who handed over the item.

(4) a certain way for delivery, by way of constitutum posessorium for moving tangible objects, or by cessie to Hufang receivables.

When examined above legal construction is the hallmark of a fiduciary agreement, that is the essence of a fiduciary agreement is an agreement of an object (material), title transfer of rights as a condition for agreement details at once to translate their legal

8 Sofwan, Sri Soedewi Masjchoen, Loc Cit. 
guarantees. In a fiduciary agreement, the authority of the master objects, which referred to the delegation of authority to control objects assurance, but this needs to be underlined the authority of mastering not be the same as the will of the master, because the will to master a part which is prohibited in the fiduciary agreement, delegation of authority over a part of responsibility given to the recipient of fiduciary fiduciary giver to complete the loan by selling the collateral objects,

Against handover constitutum posessorium, note that known some form of handover is not real, that is ${ }^{9}$ :

a. Traditio Brevi Manu, a form submission where the goods are to be delivered because of something that is already in the possession of the parties will accept delivery, such as delivery of the lease-purchase. Tenant-purchase for the leasepurchase it already controlled goods while the ownership remains in the seller, if the price of leasing, it was paid the then party seller delivers (in traditio brevi manu) goods to tenantpurchase and later became his

b. Longa Traditio Manu, a form submission where the goods are to be delivered in the possession of third parties.

For example, a buy a car from B on the condition that his car had turned over a week after the contract of sale was made. Before the one-week period had passed $A$ sell more cars to $C$ was $B$ was told by a car that was later handed

9 Mr. WM Klyn, 1978, Overview of the Dutch museum wearer Authorship Law in Law Compedum Belanda's-Graavenhage, Cooperation Foundation Science of Law Indonesia and the Netherlands, p.31.

RECONSTRUCTION OF LEGAL LIABILITY OF REGISTRATION BY over to $\mathrm{C}$ only. Form of buying and selling these have been wont to do. for businesses, will be established fiduciary guarantee agreement.

Although the practice of a fiduciary is not new in Indonesia, but the provisions of the new laws being in 1999 with nnya UUJF on September 30, 1999 and on that day was also enacted in the state aran Lemb 168 numbers.

UUJF not appear out of nowhere, but it was a reaction to the needs and the implementation of the fiduciary practices that had been running, then it would be easier for us to understand the provisions UUJF, if we understand the practice and practical problems which have ada10. The reaction is one of them is the current economic slowdown, which would need a high capital not dimbangi by providing sufficient capital, so that in the framework of the capital efficiency of the loan is only limited to the purchase of the means of production that does not exist, whereas the means of production are now no longer need to be refurbished but still used at once as part of the collateral for the loan debt for a business, the concept is a reaction to the inefficiency of the security agreement a pledge that has been known in practice, where the object guarantee must be in the control perierima pawn, thereby inhibiting conditions for the business world, then dibentulah fiduciary agreement. Article 1 of fiduciary Law provide limits and understanding the following The concept was a reaction to the inefficiency of collateral pledge agreement, which is known in practice, which guarantee object must be in possession perierima pawn, thereby inhibiting conditions for the business world, then dibentulah fiduciary 
agreement. Article 1 of Law fiduciary provide limits and understanding the following The concept was a reaction to the inefficiency of collateral pledge agreement, which is known in practice, which guarantee object must be in possession perierima pawn, thereby inhibiting conditions for the business world, then dibentulah fiduciary agreement. Article 1 of Law fiduciary provide limits and understanding the following ${ }^{10}$ :

"Fiduciary is a transfer of ownership of an object on the basis of trust with the provision that the object ownership rights transferred remains in the control of the owner of the object. Fiduciary is the right collateral to the moving objects both tangible and intangible and immovable in particular building can not be burdened security rights as stipulated in Act No. 4 of 1996 on mortgage which remain in control of the Giver Fiduciary, as collateral for repayment of certain debt, which gives precedence to the receiver position Fiduciary against other creditors ".

Receivables are right to receive payment. Matter is anything that can be owned and transferred, both tangible and intangible, registered and unregistered, moving or not moving can not be encumbered encumbrance or mortgages. Giver fiduciary is an individual or corporate owner of the object is the object of fiduciary. Debt is an obligation expressed or can be expressed in a good amount of money in the currency of Indonesia or any other currency, either directly or contingent. Creditors are parties receivable for the agreement or legislation. Each person is an individual or corporation ".

From the definition given clear to us that the fiduciary is distinguished from the fiduciary, the fiduciary is a process in which the transfer of ownership rights and the fiduciary is the guarantee provided in the form of a fiduciary. This means fiduciary institutions that are regulated in UUJF fiduciary institution as the fiduciary cum creditore contractân ${ }^{11}$ namely the guarantee that is charged on an object moves fiduciary as part of the so-called guarantees with trust, fiduciary put forward in UUJF of the understanding of the fiduciary itself, this is based on that the real intention of the fiduciary agreement made under UUJF essentially a process of relationship law in the business world that relies on the element of mutual help and goodwill on each side, this can be seen with the conception of the fiduciary and guarantees in perjanpan ridusia itself from the beginning to the development are now distinctively lack of mastery of objects guarantee by the recipient of fiduciary, whereas towards moving objects is very risky situation.

\section{Principles of Fiduciary}

Fiduciary law have the nature and principles, these properties among others, collateral material and follow-up agreement (accesoir), whereas fiduciary principles are as follows:
a. The principle predates Rights owned by creditor
b. The principle object of fiduciary who follow the object

10 BP.Cipta Jaya. Implementing Regulations Fiduciary Act of 2000. p. $84-85$
11 Gunawan Widjaja and Ahmad Yani. Op Cit. p.123-131. 
c. The principle of fiduciary is a follow-up agreement

d. The principle object of fiduciary against the contingent debt

e. The principle object of fiduciary objects that will be

f. The principle object of fiduciary on land owned by others

g. The principle object of fiduciary described in more detail

h. Giver Fiduciary Principles should be competent

i. Fiduciary Principles must be registered

j. The principle object as object fiduciary can not be owned by the creditor.

k. The principle that the fiduciary has the right priority

I. Giver Fiduciary Principles that should be acting in good faith

$\mathrm{m}$. The principle that the fiduciary is executed

All of the principles contained in the fiduciary reflect that fiduciary law has the character and unique characteristics that need to be investigated in such a way. There are still many weaknesses in the establishment of Fiduciary Act and its settings and its interpretation. To implement the principles mentioned above should in agreement Fiduciary Notary, between giver fiduciary or fiduciary Recipient Borrower or Lender, must be made in full. Starting with the signing of an agreement in principal, the Power of Attorney to register a fiduciary of the recipient of fiduciary to the Notary or Notary employees. The registration Power of Attorney can be substituted to the employees of the Notary, if the power of attorney in Fiduciary Receiver only provide power to the Notary.

\section{Fiduciary Procedures Based on pp 21, 2015}

In Article 2 of the Indonesian Government Regulation No. 21 of 2015 About Registration Procedures Fiduciary And Cost Creation Agreement of Fiduciary states that "The registration application Fiduciary, request repairs certificate Fiduciary, for amendment of the certificate of Fiduciary, and a takedown notice certificate Fiduciary filed by Recipient Fiduciary, power of attorney or his deputy to the Minister.

In this case the format of the petition must contain the elements as defined by the PP, the elements that should be included are:

a. The identity of the giver and the recipient of fiduciary Fiduciary;

b. Date, Fiduciary agreement number, the name and domicile of the notary who made the agreement Fiduciary;

c. Data principal agreement which guaranteed the fiduciary;

d. A description of the object which is the object Fiduciary;

e. The value of the guarantee; and

f. Value objects into an object Fiduciary.

The petition shall be filed after 30 (thirty) days from the making of fiduciary warranty agreement. If it fulfills the conditions, then the applicant would obtain evidence signup containing the following elements:

a. registration number;

b. date of filling the application;

c. applicant's name;

d. Fiduciary Registration Office name;

e. the type of application; and

f. Fiduciary registration fee.

The petition will be recorded electronically after the applicant 
completed the administrative costs of registration. Fiduciary shall be deemed to have been born at the time of recording by the electronic media. If it has been recorded, then the applicant can print it online and be used as evidence that the Fiduciary has been registered.

Tekait at a cost of Creation Agreement of Fiduciary as defined in Article 18 of the Indonesian Government Regulation No. 21 of 2015 About Registration Procedures Fiduciary And Cost Creation Agreement of Fiduciary explained that the creation agreement Fiduciary charged the amount determined by the value of the guarantee, with provisions following:

a. guarantee amount up to USD $100,000,000.00$ (one hundred million), the cost of making the agreement at most 2.5\% (two point five percent);

b. guarantee amount over USD $100,000,000.00$ (one hundred million rupiah) up to $1,000,000,000.00$, (one billion rupiah), the cost of making the agreement at most $1.5 \%$ (one point five percent); and

c. guarantee amount over USD $1,000,000,000.00$ (one billion rupiah), the cost of making a notary agreement by agreement between the parties, but not to exceed $1 \%$ (one percent) of the object that created aktanya.

\section{Factors Reconstruction Notary Fiduciary Carried By Pp 21, 2015.}

Article 372 of the Criminal Code emphasizes: Whoever intentionally and unlawfully possession of something that is wholly or partly belonged to someone else, but it is in his power not because of crimes punishable as fraud, with a maximum imprisonment of four years or a maximum fine of nine hundred rupiah.

By creditors, but this could be a blunder because it can each report since most of the goods become the property were both debtors and creditors, it takes civil decisions by local courts to mendudukan portion of each owner of the item for both sides. If it is taken there will be a long legal process, laborious and not cost you a bit. Consequently, the company's margins to be achieved is not realized even possible loss, including loss of time and thought.

These financial institutions that do not register themselves fiduciary actual loss because they have no legal right to eksekutorial. Poblem businesses that require speed and excellent customer service are not always in line with the logic of existing law. Perhaps because of a legal vacuum or the law is not always as fast as the times. Imagine, the fiduciary must be made before a public notary while making agreements and financing institutions in the field of fiduciary transactions in a relatively quick time.

Today many financial institutions to execute on the object that bears fiduciary goods that are not registered. Can be called remedial, rof coll, or remove. During this time the finance company they feel safe and smooth action alone. According to the authors, this is the case because it is still weak bargaining power of customers to creditors as the owner of the funds. Plus the legal knowledge society is still low. This weakness exploited by the financial industry businesses, especially financial institutions and bank sector practicing fiduciary with agreement under the hand.

The author is also concerned about the alleged pengemplangan nontax state revenue in accordance with Act No. 20 of 1997 on Non-Tax State 
Revenue, because millions of financing (consumption, manufacturing and industrial) with the fiduciary is not registered and has the greatest potential financial harm state revenues.

\section{CONCLUSION}

Fiduciary agreement is an agreement of creditors to debtors accounts payable involving guarantees. The collateral position still in control of the owner of the guarantee.But in order to ensure legal certainty for creditors then made a agreement made by the notary and registered with the Registry Office fiduciary. Later creditor will obtain a certificate of fiduciary berirah-irah Demi Justice Based on God. Thus, it has the power immediately if the debtor executorial rights violations fiduciary agreement to creditors (parate execution), in accordance with Act No. 42 of 1999 About Fiduciary.

And what about the fiduciary agreement that is not in Make a notary and registered at the registration office created under the alias fiduciary hand?
Understanding agreement under the hand is a agreement made between the parties where pembuatanya not in the presence of a valid agreement officials specified by law (notary, PPAT etc.).

Agreement under the hand is not authentic act which has no probative value is perfect. Instead, authentic agreement is a agreement made by or in front of the officials appointed by the Act and has the strength of evidence is perfect. For the agreement is done under the hand usually must diotentikan reset by the parties if you want to be used as valid evidence, for example in court. The question is whether the legitimate and have the strength of the evidence under the law of a agreement in hand? IMHO, the legitimate use as long as the parties acknowledge the existence and contents of the agreement. In practice, at home or because of certain conditions lead to a legal relationship strengthened through agreement under the hand such as the buying and selling process and debts. However, in order that the agreement is strong.

\section{BIBLIOGRAPHY}

\section{Books:}

Anis Mashdurohatun, Zaenal Arifin and Gunarto, The Inconsistency of Parate Execution Object Warranty of Rights in, International Journal of Applied Business and Economic Research, Volume 15 Number 20 year 2017.

Badrulzaman. Mariam Darus. 1996, Book of the Law of Civil Law Book III, On Hukinit Engagement With the explanation. Alumni, Bandung.

Fuady. Munir, 1997, Business Law in Theory and Practice, Citra Aditya Bakti, Bandung. Hadi. Sutrisno, 2000. Methodology Research Volume 1, Publisher ANDI Yogyakarta.

I. Gusti Ayu Ketut Rachmi Handayani, Edi As'Adi, Guntur Hamzah, Tommy Leonard, Gunarto, Relationship between Energy Consumption in International Market and Indonesia Prices

Regulation, International Journal of Energy Economics and Policy, 2017, 7(5), 9-15.

Kamelo. Tan. H, 2004. Fiduciary Law Needs A Coveted, Alumni. Bandung.

Muhammad, Abdul Kadir. Law 1990. Commitments. Citra Aditya Bakti, Bandung. 
Setiawan, R. 1979. Commitments Basic Law. Alumni, Bandung.

Soekanto. Soerjono, Introduction to Legal Research, UI Press, Jakarta, in 1986.

Soemitro. Ronny Hanitijo, 1985. Methodology of Legal Research, Ghalia Indonesia, Jakarta.

Sofwan, Sri Soedewi Masichoen. 1991, the Civil Law: Law Benda, Liberty, Jakarta.

Subekti and Tjitrosoedibio. 1970. Law Dictionary. Pradnya Paramita. Jakarta.

Sumardjono. Maria SW, 1997 Guidelines for Preparation of Proposed Research (a Basic Guide), PT. Gramedia Pustaka Utama, Jakarta.

Sutopo. HB 1998. The law Research Qualitative Methodology Part II, UNS Press, Surakarta.

Widjaja, Gunawan and Ahmad Yani, 2000 Series Business Law: Fiduciary. Rajawali Press, Jakarta.

\section{Papers:}

Patrik. Purwahid, "The Role of Materials Agreement Within the Community", a paper at a seminar Problems Standard Contracts In the Credit Agreement, the Association of Indonesian Lawyers, Surabaya, December 11th, 1993.

\section{Constitution:}

Code of Civil law.

Basic Agrarian Act No. 5 of 1960.

Act No. 42 of 1999 on Fiduciary.

Act No. 30 of 2004 on Notary.

Government Regulation No. 21 of 2015 About Registration Fiduciary

Internet:

http://pusatinformasi212.blogspot.co.id/2018/08/teori-keadilan-menurut-aristoteles-plato-thomas-

hobbes.html 